\title{
Dopamine Receptors Gene Expression in Male Rat Hippocampus after Administration of MDMA (Ecstasy)
}

\author{
La Expresión Génica de Receptores de Dopamina en el Hipocampo \\ de Ratas Macho Después de la Administración de MDMA (Éxtasis)
}

Mahakizadeh Simin"; Jahanshahi Mehrdad"*; Haidari Kamran ${ }^{* * *}$ \& Shahbazi Majid ${ }^{* * *}$

\begin{abstract}
SIMIN, M.; MEHRDAD, J.; KAMRAN, H. \& MAJID, S. Dopamine receptors gene expression in male rat hippocampus after administration of MDMA (Ecstasy). Int. J. Morphol., 33(1):301-308, 2015.

SUMMARY: Ecstasy is one of the most popular amusing drugs among young people. Documents indicate some effects of Ecstasy on hippocampus and close relations between dopaminergic functions with reward learning. Therefore, the aim of this study was evaluation of the chronic effects of Ecstasy on memory in male Wistar rats and determination of dopamine receptors' gene expression in hippocampus. Forty adult male Wistar rats randomly distributed in five groups: Control, sham (received $1 \mathrm{ml} / \mathrm{kg} 0.9 \%$ saline) and three experimental groups were: Exp. 1 (2.5 mg/kg), Exp. $2(5 \mathrm{mg} / \mathrm{kg})$, and Exp. $3(10 \mathrm{mg} / \mathrm{kg})$ received MDMA intraperitoneally once every 7 days ( 3 times a day, 3 hours apart) for 4 weeks. Before the first injection animals trained in Shuttle Box memory and tested after the last injection. 24 hours after the final testing, brains of rats were dissected and hippocampus was removed and homogenized. After total RNA extraction and cDNA synthesis, expression of dopamine receptor genes in the hippocampus determined with Real-Time PCR. Our results showed that 2.5 and $5 \mathrm{mg} / \mathrm{kg}$ MDMA-treated groups had memory impairment. Also we found that MDMA increased the mRNA expression of dopamine receptors in hippocampus and the highest increase found in dopamine D1 receptors in the $5 \mathrm{mg} / \mathrm{kg}$ experimental group. We concluded that low doses of Ecstasy could increase Dopamine takers gene expression in hippocampus and disorder avoidance memory. But in high doses the increase in Dopamine takers gene expression was not as much as that in low doses and avoidance memory disorder was not observed.
\end{abstract}

KEY WORDS: MDMA; Dopamine Receptors; Gene expression; Hippocampus; Rat.

\section{INTRODUCTION}

Today MDMA (3,4-methylenedioxymetamphetamine) is one of the most popular drugs among the young, especially at dance parties because of its ability to induce attraction and increasing energy (Cohen 1995; Kindlundh-Högberg et al., 2006). Ecstasy (MDMA) acts as a stimulant and mescaline-like hallucinogen, and is known to suppress the appetite (Cohen; Green et al., 2003).

Frequent and prolonged use of MDMA causes depression, anxiety and aggression, but it has also been accompanied with cognitive changes, loss of shyness, impulsivity, memory loss, and eating disorders in human and rats (Cohen; Morgan, 1998; McCann et al., 1999; Morley et al., 2001; Curran et al., 2004; McCardle et al., 2004; Gouzoulis-Mayfrank et al., 2005; Kindlundh-Högberg et al.).
Some documents indicate a close relations in hippocampus between dopaminergic functions of reward related-associative learning (Di Chiara, 1999), reward prediction and incentive salience (Berridge \& Robinson, 1998; Schultz 1998; Everitt et al., 1999), and serotonergic functions of disinhibition and impulsivity (Linnoila et al., 1983; Af Klinteberg et al., 1990; Winstanley et al., 2004) because of numerous specific interactions between the two systems.

The issue whether compulsive MDMA-taking behavior mostly is regulated by dopamine or serotonin related functions is very important to understand the implication and role of MDMA in mechanisms of addictive behaviors (Kindlundh-Högberg et al.).

\footnotetext{
* Department of Anatomy, Neuroscience Research Center, Golestan University of Medical Sciences, Gorgan, Iran.

** Associate Professor of Anatomy, Department of Anatomy, Neuroscience Research Center, Golestan University of Medical Sciences, Gorgan, Iran.

*** Cellular and Molecular Research Center, Golestan University of Medical Sciences, Gorgan, Iran.
} 
There are several limitations in accompanying researches on MDMA-taking; for example, ecstasy is administered in dose regimes that poorly imitate the behaviors observed among young person's taking this drug on a weekly or at least intermittent basis at dance clubs. Instead MDMA, in most previous studies, was either administered as a single dose or multiple doses for 17 days (Gold \& Koob, 1989; Taylor \& Jentsch, 2001; Fone et al., 2002; McGregor et al., 2003). Secondly, studies of MDMA caused long-term effects have focused on mechanisms that occur some days after drug discontinuation reflecting peripheral or withdrawal effects rather than effects of repeated long-term intake (Green et al.). Third, several studies have reported effects upon behavior (locomotion, conditioned place preference, self-administration), protein density (autoradiography), neurotransmitters and their metabolites (micro dialysis) (Green et al.; Piper \& Meyer, 2004), but it still remains unclear whether observed alterations also involve changes in mRNA contents of included markers. Finally, many studies have focused on single or a few markers in single brain structures, and there is no comprehensive testing of dopaminergic and serotonergic markers simultaneously in multiple brain regions (Kindlundh-Högberg et al.).

We hypothesize that alterations of gene transcript levels of markers implicated in mechanisms regulating rewarding properties underlie the psychiatric changes that have been reported to be associated with MDMA intake. The specific aim of the present study was to investigate how the repeated intermittent administration of MDMA affects the gene-transcript content of dopamine receptors in regions of the male rat hippocampus implicated in memory loss.

\section{MATERIAL AND METHOD}

Animals. Eight week male Wistar rats (Pasteur Institute, Tehran, Iran) weight $200 \pm 20 \mathrm{~g}$ at the initiation of the study, served as subjects and were housed pair-wise in air conditioned rooms (12:12-h dark/light cycle) at $22 \pm 3{ }^{\circ} \mathrm{C}$ and a humidity of $53 \%$. The rats were randomly distributed into three MDMA-treated (-3,4-methylenedioxy-Nmethamphetamine-HCl), Sigma Pharmaceutical) and Sham groups. All animals received three intraperitoneal injections (3 $\mathrm{h}$ apart; a challenge) every 7 day for 4 weeks. The MDMA was dissolved into the vehicle on the day of testing. During the treatment day the MDMA low-dose $(\mathrm{n}=8)$ received 3 $2.5 \mathrm{mg} / \mathrm{kg}$ MDMA, the MDMA middle dose $(\mathrm{n}=8) 3 \times 5$ $\mathrm{mg} / \mathrm{kg}$, the MDMA high dose rats $(\mathrm{n}=8) 3 \times 10 \mathrm{mg} / \mathrm{kg}$ whereas Sham group received the vehicle of sterile $0.9 \%$ saline solution $(1 \mathrm{ml} / \mathrm{kg})$. The rationale for these doses of
MDMA stems from human conditions. MDMA is taken at doses of $50-60 \mathrm{mg}$ in humans. One single dose of $5 \mathrm{mg} / \mathrm{kg}$ per rat corresponds to $65 \mathrm{mg}$ in a $65 \mathrm{~kg}$ human according to the interspecies scaling technique: $\mathrm{D}$ human $=\mathrm{D}$ animal $(\mathrm{W}$ human/W animal) 0.7 (Mordenti et al., 1991). The Golestan University of Medical sciences Guidelines for the Care and Use of Animals in Research were followed.

Inhibitory Avoidance Apparatus. The step-through inhibitory avoidance apparatus consisted of two compartments of the same size $\left(20 \times 20 \times 30 \mathrm{~cm}^{3}\right)$. In the middle of a dividing wall, a guillotine door $\left(7.9 \mathrm{~cm}^{2}\right)$ could be lifted manually. The walls and floor of one compartment consisted of white opaque resin and the walls of the other compartment were dark. Stainless steel bars $(3 \mathrm{~mm}$ in diameter and $1 \mathrm{~cm}$ intervals) constituted the floor of the dark compartment. Intermittent electric shocks $(50 \mathrm{~Hz}, 3 \mathrm{~s}, 1.5$ $\mathrm{mA}$ intensity) were delivered to the grid floor of the dark compartment by an isolated stimulator.

Behavioral Procedures. Our previous study (Azami et al., 2010) described passive avoidance as follows: All animals were allowed to habituate in the experimental room (with light and sound attenuated) for at least $30 \mathrm{~min}$ prior to the experiments. Then, each animal was gently placed in the brightly lit compartment of the apparatus; after $5 \mathrm{~s}$ the guillotine door was opened and the animal was allowed to enter the dark module.

The latency with which the animal entered the dark chamber was recorded. Animals that waited more than 120 $s$ to enter the dark chamber were excluded from the experiments.

Once the animal entered with all four-paws to the next chamber, the guillotine door was closed and the rat was immediately withdrawn from the compartment. This trial was repeated after $30 \mathrm{~min}$. As in the acquisition trial, after 5 $\mathrm{s}$ the guillotine door was opened, and as soon as the animal entered the dark (shock) compartment the door was closed; and a foot shock (50 Hz, $1 \mathrm{~mA}$ and $3 \mathrm{~s})$ was immediately delivered to the grid floor of the dark room. After $20 \mathrm{~s}$, the rat was removed from the apparatus and placed temporarily into its home cage. Two minutes later, the animal was retested in the same way as in the previous trials; if the rat did not enter the dark compartment during $120 \mathrm{~s}$, a successful acquisition of inhibitory avoidance response was recorded. Otherwise, when the rat entered the dark compartment (before $120 \mathrm{~s}$ ) a second time, the door was closed and the animal received the shock again. After retesting, if the rat learned inhibitory avoidance response successfully, it was moved to the cage. On the test day each animal was gently placed in the light compartment and after $5 \mathrm{~s}$ the door was 
opened, and step through latency (sec) was recorded in the absence of electric foot shocks, as indicator of inhibitory avoidance behavior.

Thirty minutes after the last injection of MDMA the rats tested in Shuttle box and $24 \mathrm{~h}$ after the final test, the brains of rats were dissected.Brain region of interest hippocampus (at bregma 4.8 to 5.6), were dissected using a rat brain matrix (Paxinos \& Watson, 2007), rapidly frozen on dry ice, immersed in RNA later (Ambion) for $1 \mathrm{~h}$, and then stored at $-80{ }^{\circ} \mathrm{C}$. All procedures were performed in accordance with institutional guidelines for animal care and use.

Isolation of total RNA and reverse transcriptase. After homogenizing of the hippocampus tissue, total RNA were isolated with RNeasy Mini Kits (Qiagen, Germany), following the manufacturers protocol and recovered in 20 $\mu \mathrm{L}$ elution solution. Then, reverse transcription was done with equal amounts of RNA using Omniscript kit Qiagen, Germany) to generate cDNA template for real-time polymerase chain reaction (PCR) according to the manufacturer's protocol. The cDNA templates were evaluated by PCR and gel-electrophoresis.

Quantitative Real-Time PCR. Quantitative real-time PCR (Q RT-PCR) was used blindly on the samples (ABI 7300; USA) using the Power SYBR Green PCR Master Mix (Applied Biosystems) to analyze the transcript levels of dopamine receptors in total volume $25 \mu 1$.

Amplification was done for $\mathbf{4 0}$ cycles at four stages: Stage 1: $50{ }^{\circ} \mathrm{C}$ for 2 minutes; Stage 2: $95^{\circ} \mathrm{C}$ for 1 minute; Stage 3: $95{ }^{\circ} \mathrm{C}$ for 15 seconds and $62{ }^{\circ} \mathrm{C}$ for 1.5 minutes;
Stage 4: $95^{\circ} \mathrm{C}$ for 15 seconds, $60{ }^{\circ} \mathrm{C}$ for 30 seconds and 95 ${ }^{\circ} \mathrm{C}$ for 15 seconds.

Primers used for Q RT-PCR. Primers pairs of the internal housekeeping gene (s18 RNA) and the dopamine receptors were designed to Primers-3 software and National Center for Biotechnology Information (NCBI):

Primers of s18 RNA; gtgatccccgagaagtttca; ctgcttcctcaacaccaca

Dopamine D1 receptor primer; tccttcaagagggagacgaa; ccacacaaacacatcgaagg

Dopamine D4 receptor primer; gatgtgttggacgcctttct; tcggcattgaagatggtgta

Dopamine D5 receptor primer; ccacatgataccgaatgcag; cacagtcaagctcccagaca

Statistical analysis. Statistical analyses for memory experiment were performed using one-way ANOVA. Gene expression fold was calculated relative to the level of each sample of the housekeeping gene, S18 RNA using Microsoft Excel ${ }^{\circledR} 2^{-\Delta \Delta \mathrm{ct}}=\operatorname{PRODUCT}\left(2^{\wedge}-((\mathrm{A} 4-\mathrm{B} 4)-(\mathrm{C} 4-\mathrm{D} 4))\right)$. The differences with $\mathrm{P}<.05$ were considered statistically significant.

\section{RESULTS}

As we show in Figure 1, the present study showed that the Saline group got amnesia due to the lapse of time with the average of $27.5 \mathrm{~s}$ delay in entering the black house/ cell. But it seemed that the Ecstasy effected the recalling of the memory in experimental group and because of the amount of dose rats got less amnesia. In other words most of rats

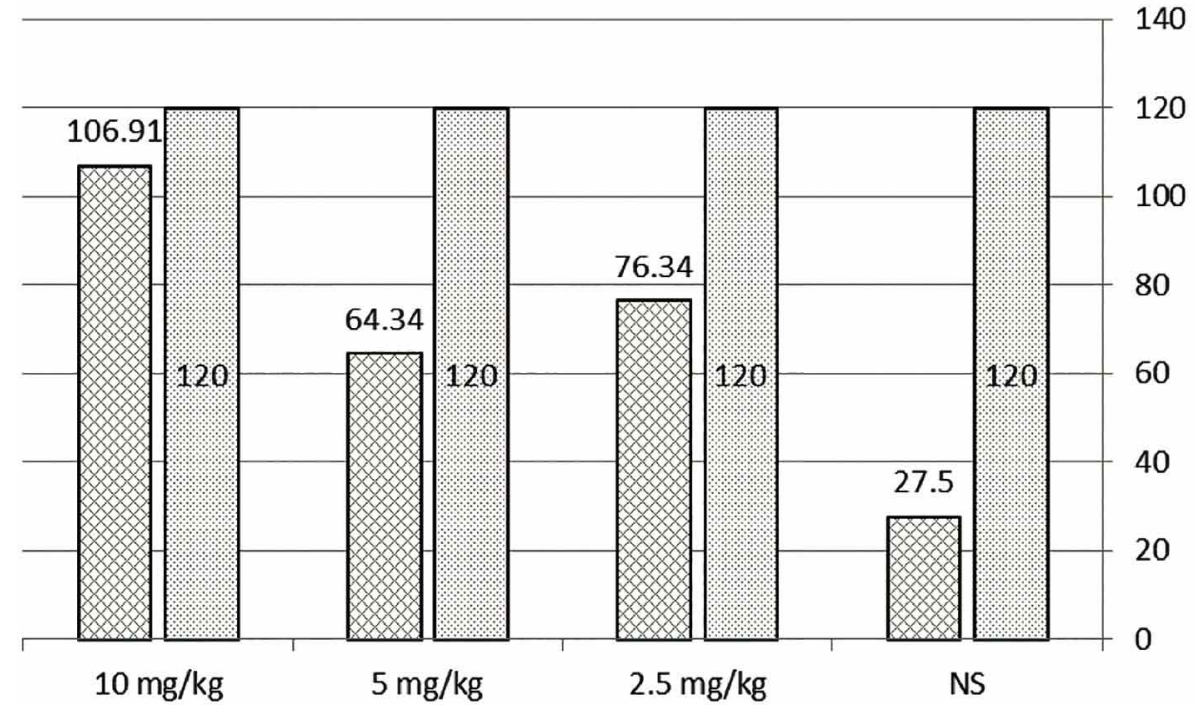

Fig. 1. Delay time (per second) to entrance to dark chamber after one month. 


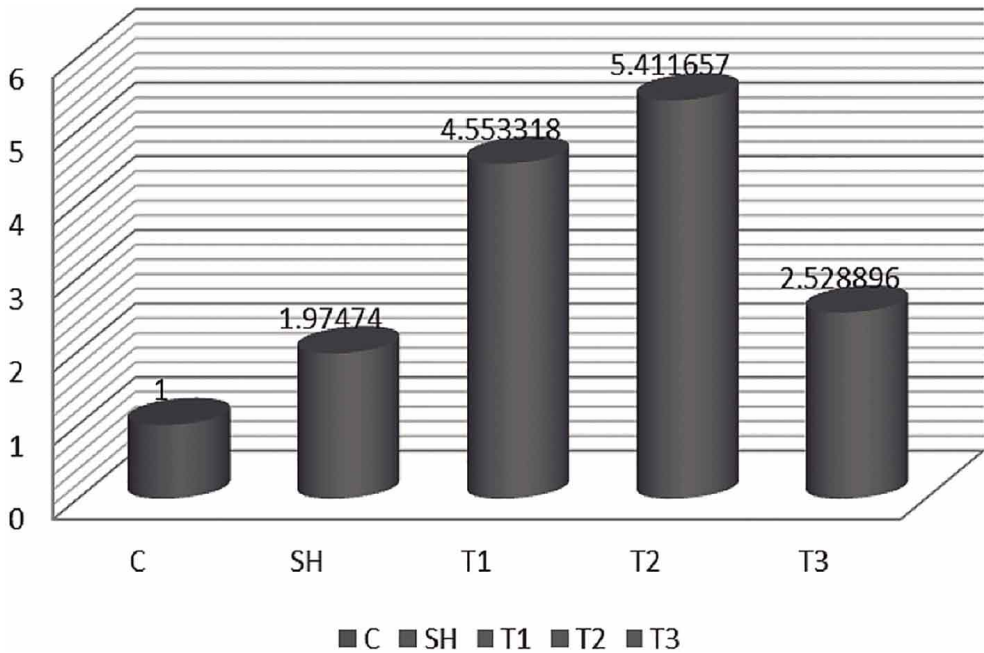

Fig. 2. D1 Dopamine receptor genes expression in all groups. $\mathrm{C}=\mathrm{Control}, \mathrm{SH}=$ Sham, $\mathrm{T} 1=2.5 \mathrm{mg} / \mathrm{kg}, \mathrm{T} 2=5 \mathrm{mg} / \mathrm{kg}$ and $\mathrm{T} 3=10 \mathrm{mg} / \mathrm{kg}$ MDMA.

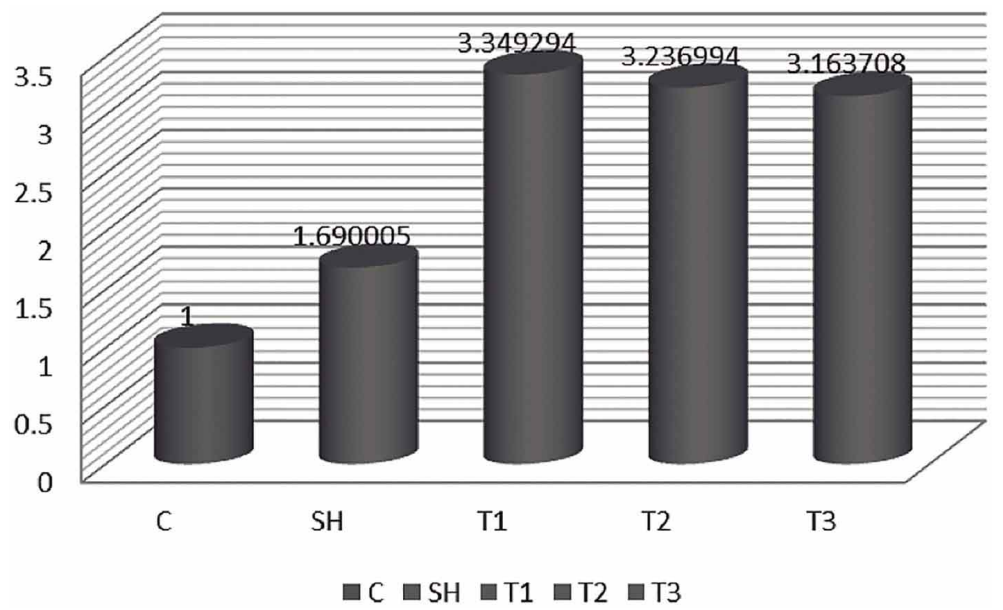

Fig. 3. D4 Dopamine receptor genes expression in all groups. $\mathrm{C}=\mathrm{Control}, \mathrm{SH}=$ Sham, $\mathrm{T} 1=2.5 \mathrm{mg} / \mathrm{kg}, \mathrm{T} 2=5 \mathrm{mg} / \mathrm{kg}$ and $\mathrm{T} 3=10 \mathrm{mg} / \mathrm{kg}$ MDMA.

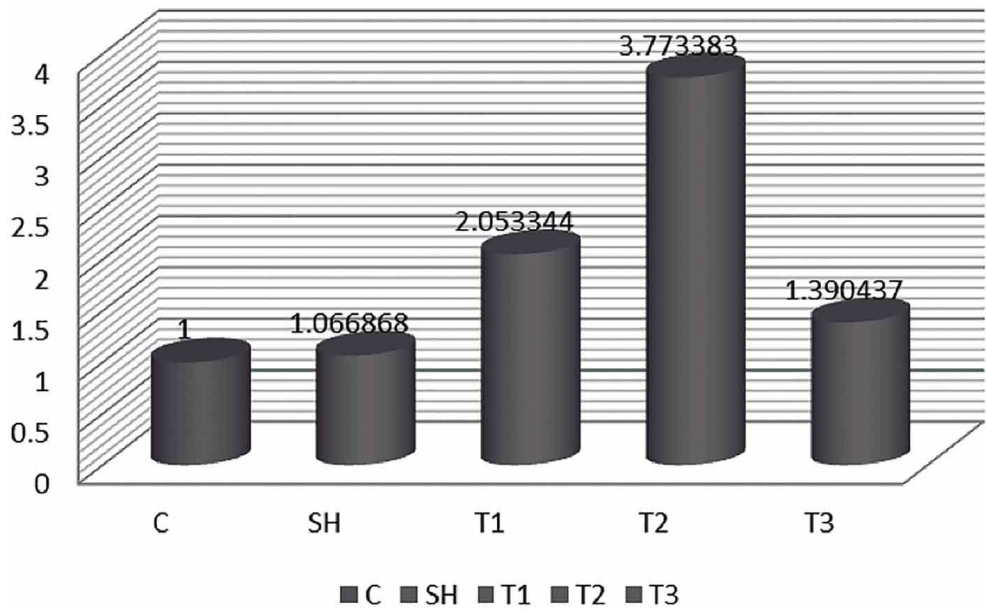

Fig. 4. D5 Dopamine receptor genes expression in all groups. $\mathrm{C}=\mathrm{Control}, \mathrm{SH}=$ Sham, $\mathrm{T} 1=2.5 \mathrm{mg} / \mathrm{kg}, \mathrm{T} 2=5 \mathrm{mg} / \mathrm{kg}$ and T3 $=10 \mathrm{mg} / \mathrm{kg}$ MDMA. with complete memory/recall were observed in $10 \mathrm{mg} / \mathrm{kg}$ dose (Fig. 1).

The expression profiles of these three genes relative to s18 RNA showed that the injection of MDMA increase the D1, D4, and D5 Dopamine receptors gene expression in comparison with control and control-Saline groups.

Considering this point is essential that diagram of this gene expression changes is sinuous and its peak is in T2 $(5 \mathrm{mg} / \mathrm{kg}$ MDMA). In other words the most increase of gene expression was observed for all three Dopamine takers in this group.

D1, D4 and D5 receptors gene expression in $2.5 \mathrm{mg} / \mathrm{kg}$ group were increased in comparison with Sham. The highest expression of the receptor revealed in D1 receptor (Figs. 2-4).

D1, D4 and D5 receptors gene expression in $5 \mathrm{mg} / \mathrm{kg}$ group had a higher level in comparison with Sham. Also the highest expression of the receptors revealed in D1 receptor while D4 receptor gene expression in this group is not much difference in comparison with low dose group (Fig. 2-4).

D1, D4 and D5 receptors gene expression in 10 $\mathrm{mg} / \mathrm{kg}$ group were increased. Also the highest expression of the receptors revealed in D4 receptor and also D4 receptor gene expression in this group is not much difference in comparison with 2.5 and $5 \mathrm{mg} / \mathrm{kg}$ dose group (Figs. 2-4).

\section{DISCUSSION}

There are several behavioral patterns to test memory and learning in laboratory animals. But during recent years passive avoidance memory as a learning model has been used extensively (Azami et al.). The present study showed that taking 2.5 and $5 \mathrm{mg} / \mathrm{kg}$ doses of MDMA over long periods (4 weeks) destroyed memory on one hand, and increased the gene expression Dopamine receptors, although taking $10 \mathrm{mg} / \mathrm{kg}$ of MDMA over long periods (4 weeks) had no destructive effects on memory in spite 
of decreasing in the gene expression Dopamine receptors, comparing to other experimental groups; although, it was more than the performance of gene expression Dopamine receptors group which showed that beside the instruction of animals, taking MDMA was effective on memory and the level of gene expression.

Another considerable point was our given Dopamine receptors different reactions to MDMA. Dopamine receptors were divided into two groups of D1like (D1, D5) and D2-like (D2, D3, D4) (Brennan et al., 2009). In this study we observed that the Maximum level of gene expression Dopamine receptors of D2-like (D2, D3, D4) meant D4 sustained little change by the increase of MDMA dose. But the level of gene expression Dopamine takers of D1-like (D1, D5) had considerable changes by the alternation of MDMA dose. Therefore, probably, the takers expression of D1-like (D1, D5) was largely related to the dose of drug while the maximum of the takers expression of D2-like (D2, D3, D4) was in specific dose and with the increase of drug not so much changes did not observed. Behavioral disorders were reported among people who took Amphetamine for 3 months (Richards et al., 1993).

Amphetamine caused permanent behavioral disorders Morris Maze Water (MMW) among animals that took (Friedman et al., 1998), Also METH and parachloroamphetamine (PCA) caused drawback in passive avoidance (PA) learning and considerable decrease in their Dopamine, Serotonin, and their metabolisms in different regions of brain. In contrast, taking MDMA decreased Dopamine in anterior striatum and cingulated and did not disorder avoidance memory (Murnane et al., 2012).

MDMA, METH and PCA have different abilities in avoidance memory due to their different neuro-chemical effects. In this regard METH and PCA destruct avoidance memory while MDMA neither caused the secretion of neurotransmitters nor avoidance memory disorders (Murnane et al.). The researchers also showed in the present that higher doses of MDMA did not destruct avoidance memory, but they did not find similar cases regarding the Dopamine receptors gene expression. Previous studies showed that avoidance memory did not dependent on Serotonin (Santucci et al., 1996; Barrionuevo et al., 2000; Myhrer, 2003). Moreover, Serotonin did not decrease by METH and PCA. The present report confirmed the previous studies which showed that avoidance memory was mediated by Dopaminergic system (Sugimoto et al., 2001). On the other hand, processes related to Dopamine which were related to memory and learning might be disordered because of Amphetamine (Murnane et al.).
The results of this study also confirmed that Amphetamine derivatives could disorder the avoidance memory. Although no memory disorder was observed in high MDMA dose (10 mg/kg).

Those who take sustain prolonged habits (Williamson et al., 1997). It is essential to consider this point that although memory and learning disorders exist among MDMA takers (Kalechstein et al., 2007), but the results of the present study did not completely match with the previous studies; this might be due to the memory and learning complicated process and the point that each Amphetamine compounds causes special disorder (Murnane et al., 2012).

Regarding to this point it is hard to generalize the results of an animal study to one of people addicted to Amphetamine. On the other hand, avoidance memory can show memory disorders but it can be used just as a preclinical investigation (Kalechstein et al.). Therefore, comparing the results of this study to the reports about addiction can be useful in finding a way to treat the disorders (Murnane et al.).

It was shown in previous studies that MDMA takers had neurotic disorders in Hippocampus. Its long term intake affected Serotonin and lead to hippocampus memory disorders (Gudelsky \& Yamamoto, 2008). Moreover Serotonergic neurons in median raphe which are targeted by hippocampus neurons activates $5 \mathrm{HT}_{1 \mathrm{~A}}$-rec in neurogenesis in dentate gyrus (Azami et al., 2009).

Recently in post mortem studies it has been reported that individuals with long term Met Amphetamine (METH) background sustained low level of Dopamine, Tyrosine, Hydroxylase, and Dopamine vectors (Wilson et al., 1996). In similar research in vivo the decrease in the amount of Dopamine vectors among METH takers were reported (McCann et al., 1998). But considering the possibility of operational differences in various Amphetamines in the present study, the researchers showed that MDMA increased Amphetamine receptors which were related to dose, taking high doses of Amphetamine compounds of Dopaminergic and Serotonergic systems in lab animals' brain (Bittner et al., 1981). Investigations have showed that prolonged Amphetamine (6-8 months) decreased Dopamine and Serotonin levels in brain tissue (Sanders-Bush et al., 1975; Friedman et al.; Cass \& Manning, 1999).

In several previous studies it has been shown that PVA specifically provokes Serotonin secretion (Steranka et al., 1977; Steranka \& Sanders-Bush, 1980; Adriani et al., 1998), meanwhile some other studies showed that PCA effects were mediated by Dopaminergic activities (O'Callaghan \& Miller, 1994; Itzhak et al., 2004). Moreover, PCA dose influenced 
the amount of Dopamine and Serotonin secretion (Stone $e t$ al., 1987). Studies on the effects of MDMA and METH on small mice showed the influence of Dopaminergic (Hirata $e t$ al., 1995; Renoir et al., 2008) and Serotonergic (Scatton et al., 1980; Shankaran \& Gudelsky, 1998) systems.

It is not clear yet why such discrepancies are observed but it seems the obtained results are affected by laboratory conditions such as drug dose, amount of training to animals, race differences and etc. (Murnane et al.).

PCA had high capacity to secrete Serotonin while both MDMA and METH decreased Serotonin level in six regions of brain (hippocampus, hypothalamus, PFC, NACs, striatum, brain stem) (Murnane et al.).

These three compounds cause secretion of Dopamine in post striatum but METH and PCA specifically decrease Dopamine level in ant striatum. Although these three compounds decrease Dopamine metabolite; Dopamine in post striatum, but only METH and PCA specifically cause the secretion of DOPAC in ant striatum and increase of hydroxyl-vanillic acid (HVA) in post striatum. In the same way only METH and PCA increase the textual level of metabolic Serotonin, 5-HLAA in frontal cortex and cingulate (Murnane et al.).

Although Hippocampus plays a main role in memory and learning process, but doesn't change in Serotonin receptors gene expression as a consequence of MDMA taking in this region of the brain. But in hypothalamus the increase in $5 \mathrm{HT}_{2 \mathrm{C}}$ and $5 \mathrm{HT}_{3}$ receptors gene expression is observed and in this region some changes in Dopamine receptors gene expression by increasing expression in D3-rec (in high and low dose of MDMA taking). Actually, Dopamine receptors gene expression in limbic system and nigrostriatum are not influenced by MDMA (Kindlundh-Högberg et al.).

Hippocampus is innervated by Dopamine neurons (Scatton et al.) and addiction to MDMA is also the result of progressive increase in Dopamine in hippocampus (Shankaran \& Gudelsky), but this increase does not happen in striatum. It was also shown that nervous noradrenergic terminals were the sources of increase in outer cell surface of Dopamine in Hippocampus on the influence MDMA which this mechanism itself was influenced by the increase of amine tyrosine acid in brain (Shankaran \& Gudelsky).

MDMA in mature mice increased proliferation in dentate gyrus and, of course, decrease progenitor cells. But those results did not show the same effects in animal took low dose $(1.25 \mathrm{mg} / \mathrm{kg})$ and medium dose $(2.5 \mathrm{mg} / \mathrm{kg})$ (Catlow et al., 2010).
In vitro studies demonstrated that the addiction to MDMA differentiated neuron cells from neural stem cells in granular layer in dentate gyrus (Azami et al., 2009); while other studies showed that MDMA could cause neurogenesis (Catlow et al.).

\section{CONCLUSION}

This study revealed that low doses of Ecstasy could increase Dopamine takers gene expression in hippocampus and disorder avoidance memory. But in high doses the increase in Dopamine takers gene expression was not as much as that in low doses and avoidance memory disorder was not observed.

\section{ACKNOWLEDGMENTS}

The authors would like to thank of the Neuroscience Research Center and the Cell and Molecular research center. We are also thankful for financial support of Research and Technology department of Golestan University of Medical Sciences.

SIMIN, M.; MEHRDAD, J.; KAMRAN, H. \& MAJID, S. La expresión génica de receptores de dopamina en el hipocampo de ratas macho después de la administración de MDMA (éxtasis). Int. J. Morphol., 33(1):301-308, 2015.

RESUMEN: El éxtasis es una de las drogas de diversión más populares entre los jóvenes. La investigación reporta algunos de los efectos del éxtasis sobre el hipocampo y la relación entre las funciones dopaminérgicas con la recompensa en el aprendizaje. El objetivo de este estudio fue la evaluación de los efectos crónicos del éxtasis en la memoria de ratas macho Wistar y la determinación de la expresión de genes receptores de dopamina en el hipocampo. Cuarenta ratas macho adultas fueron distribuidas al azar en cinco grupos: grupo control, simulado (a $1 \mathrm{ml} / \mathrm{kg}$ $0,9 \%$ de solución salina) y tres grupos experimentales: Grupo exp. $1(2,5 \mathrm{mg} / \mathrm{kg})$, Exp. $2(5 \mathrm{mg} / \mathrm{kg})$, y Exp. $3(10 \mathrm{mg} / \mathrm{kg})$ recibió MDMA vía intraperitoneal cada 7 días (3 veces al día, con 3 horas de diferencia) durante 4 semanas. Antes de la primera inyección los animales fueron entrenados en memoria Shuttle Box y examinados después de la última inyección. Veinticuatro horas después de la prueba final, los cerebros de las ratas fueron diseccionados, el hipocampo fue separado y homogeneizado. Después de la extracción total de ARN y síntesis de ADNc, la expresión de genes de los receptores de dopamina en el hipocampo fue determinado con PCR en tiempo real. Nuestros resultados mostraron que los grupos de $2,5 \mathrm{~kg}$ y $5 \mathrm{mg} / \mathrm{MDMA}$ tratados tenían deterioro de la memoria. Además, encontramos que la MDMA aumentó la expresión de ARNm de los receptores 
de dopamina en el hipocampo y el aumento mayor se observó en los receptores D1 de dopamina en el $5 \mathrm{mg} / \mathrm{kg}$ Grupo experimental. En conclusión, las dosis bajas de éxtasis podrían aumentar tomadores de expresión génica de la dopamina en el hipocampo y trastornos de la memoria. Sin embargo, en dosis altas el aumento de la expresión génica no mostró un aumento significativo, a diferencia de los resultados con dosis bajas, tampoco se observaron trastornos disociativos de memoria.

PALABRAS CLAVE: MDMA; Receptores de dopamina; Expresión génica; Hipocampo; Rata.

\section{REFERENCES}

Adriani, W.; Felici, A.; Sargolini, F.; Roullet, P.; Usiello, A.; Oliverio A. \& Mele A. N-methyl-D-aspartate and dopamine receptor involvement in the modulation of locomotor activity and memory processes. Exp. Brain Res., 123(1-2):52-9, 1998.

af Klinteberg, B.; Oreland, L.; Hallman, J.; Wirsén, A.; Levander, S. E. \& Schalling, D. Exploring the connections between platelet monoamine oxidase activity and behavior: relationships with performance in neuropsychological tasks. Neuropsychobiology, 23(4):188-96, 1990.

Azami, A.; Pasbakhsh, P.; Akbari, M.; Barbarestani, M.; Ghahremani, M.; Shokrgozar, M. \& Hassanzadeh, G. Dual effects of 3, 4methylenedioxymethamphetamine (ecstasy) on survival and apoptosis of primary hippocampal neurons. Neural Regen. Res., 4(12):1068-72, 2009.

Azami, N. S.; Piri, M.; Oryan, S.; Jahanshahi, M.; Babapour, V. \& Zarrindast, M. R. Involvement of dorsal hippocampal alpha-adrenergic receptors in the effect of scopolamine on memory retrieval in inhibitory avoidance task. Neurobiol. Learn. Mem., 93(4):455-62, 2010.

Barrionuevo, M.; Aguirre, N.; Del Rı́o, J. D. \& Lasheras, B. Serotonergic deficits and impaired passive-avoidance learning in rats by MDEA: a comparison with MDMA. Pharmacol. Biochem. Behav., 65(2):23340, 2000.

Berridge, K. C. \& Robinson, T. E. What is the role of dopamine in reward: hedonic impact, reward learning, or incentive salience? Brain Res. Brain Res. Rev., 28(3):309-69, 1998.

Bittner, S. E.; Wagner, G. C.; Aigner, T. G. \& Seiden, L. S. Effects of a high-dose treatment of methamphetamine on caudate dopamine and anorexia in rats. Pharmacol. Biochem. Behav., 14(4):481-6, 1981.

Brennan, K. A.; Carati, C.; Lea, R. A.; Fitzmaurice, P. S. \& Schenk, S. Effect of D1-like and D2-like receptor antagonists on methamphetamine and 3,4-methylenedioxymethamphetamine selfadministration in rats. Behav. Pharmacol., 20(8):688-94, 2009.

Cass, W. A. \& Manning, M. W. Recovery of presynaptic dopaminergic functioning in rats treated with neurotoxic doses of methamphetamine. J. Neurosci., 19(17):7653-60, 1999.

Catlow, B. J.; Badanich, K. A.; Sponaugle, A. E.; Rowe, A. R.; Song, S.; Rafalovich, I.; Sava, V.; Kirstein, C. L. \& Sanchez-Ramos, J. Effects of MDMA ("ecstasy") during adolescence on place conditioning and hippocampal neurogenesis. Eur. J. Pharmacol., 628(1-3):96-103, 2010.
Cohen, R. S. Subjective reports on the effects of the MDMA ('ecstasy') experience in humans. Prog. Neuropsychopharmacol. Biol. Psychiatry, 19(7):1137-45, 1995.

Curran, H. V.; Rees, H.; Hoare, T.; Hoshi, R. \& Bond, A. Empathy and aggression: two faces of ecstasy? A study of interpretative cognitive bias and mood change in ecstasy users. Psychopharmacology (Berl.), 173(3-4):425-33, 2004.

Di Chiara, G. Drug addiction as dopamine-dependent associative learning disorder. Eur. J. Pharmacol., 375(1-3):13-30, 1999.

Everitt, B. J.; Parkinson, J. A.; Olmstead, M. C.; Arroyo, M.; Robledo, P. \& Robbins, T. W. Associative processes in addiction and reward. The role ofamygdala-ventral striatal subsystems. Ann. N. Y. Acad. Sci., 877:412-38, 1999

Fone, K. C.; Beckett, S. R.; Topham, I. A.; Swettenham, J.; Ball, M. \& Maddocks, L. Long-term changes in social interaction and reward following repeated MDMA administration to adolescent rats without accompanying serotonergic neurotoxicity. Psychopharmacology (Berl.), 159(4):437-44, 2002.

Friedman, S. D.; Castañeda, E. \& Hodge, G. K. Long-term monoamine depletion, differential recovery, and subtle behavioral impairment following methamphetamine-induced neurotoxicity. Pharmacol. Biochem. Behav., 61(1):35-44, 1998.

Gold, L. H. \& Koob, G. F. MDMA produces stimulant-like conditioned locomotor activity. Psychopharmacology (Berl.), 99(3):352-6, 1989.

Gouzoulis-Mayfrank, E.; Fischermann, T.; Rezk, M.; Thimm, B.; Hensen, G. \& Daumann, J. Memory performance in polyvalent MDMA (ecstasy) users who continue or discontinue MDMA use. Drug Alcohol Depend., 78(3):317-23, 2005.

Green, A. R.; Mechan, A. O.; Elliott, J. M.; O'Shea, E. \& Colado, M. I. The pharmacology and clinical pharmacology of 3,4methylenedioxymethamphetamine (MDMA, "ecstasy"). Pharmacol. Rev., 55(3):463-508, 2003.

Gudelsky, G. A. \& Yamamoto, B. K. Actions of 3,4methylenedioxymethamphetamine (MDMA) on cerebral dopaminergic, serotonergic and cholinergic neurons. Pharmacol. Biochem. Behav., 90(2):198-207, 2008.

Hirata, H.; Ladenheim, B.; Rothman, R. B.; Epstein, C. \& Cadet, J. L. Methamphetamine-induced serotonin neurotoxicity is mediated by superoxide radicals. Brain Res., 677(2):345-7, 1995.

Itzhak, Y.; Achat-Mendes, C. N.; Ali, S. F. \& Anderson, K. L. Long-lasting behavioral sensitization to psychostimulants following pchloroamphetamine-induced neurotoxicity in mice. Neuropharmacology, 46(1):74-84, 2004.

Kalechstein, A. D.; De La Garza, R. 2nd.; Mahoney, J. J. 3rd.; Fantegrossi, W. E. \& Newton, T. F. MDMA use and neurocognition: a meta-analytic review. Psychopharmacology (Berl.), 189(4):531-7, 2007.

Kindlundh-Högberg, A. M.; Svenningsson, P. \& Schiöth, H. B. Quantitative mapping shows that serotonin rather than dopamine receptor mRNA expressions are affected after repeated intermittent administration of MDMA in rat brain. Neuropharmacology, 51(4):838-47, 2006.

Linnoila, M.; Virkkunen, M.; Scheinin, M.; Nuutila, A.; Rimon, R. \& Goodwin, F. K. Low cerebrospinal fluid 5-hydroxyindoleacetic acid 
concentration differentiates impulsive from nonimpulsive violent behavior. Life Sci., 33(26):2609-14, 1983.

McCann, U. D.; Mertl, M.; Eligulashvili, V. \& Ricaurte, G. A. Cognitive performance in (+/-) 3,4-methylenedioxymethamphetamine (MDMA, "ecstasy") users: a controlled study. Psychopharmacology (Berl.), 143(4):417-25, 1999

McCann, U. D.; Wong, D. F.; Yokoi, F.; Villemagne, V.; Dannals, R. F. \& Ricaurte, G. A. Reduced striatal dopamine transporter density in abstinent methamphetamine and methcathinone users: evidence from positron emission tomography studies with $[11 \mathrm{C}] \mathrm{WIN}-35,428$. J. Neurosci., 18(20):8417-22, 1998.

McCardle, K.; Luebbers, S.; Carter, J. D.; Croft, R. J. \& Stough, C. Chronic MDMA (ecstasy) use, cognition and mood. Psychopharmacology (Berl.), 173(3-4):434-9, 2004.

McGregor, I. S.; Clemens, K. J.; Van der Plasse, G.; Li, K. M.; Hunt, G. E.; Chen, F. \& Lawrence, A. J. Increased anxiety 3 months after brief exposure to MDMA ("Ecstasy") in rats: association with altered 5-HT transporter and receptor density. Neuropsychopharmacology, 28(8):147284, 2003.

Mordenti, J.; Chen, S. A.; Moore, J. A.; Ferraiolo, B. L. \& Green, J. D. Interspecies scaling of clearance and volume of distribution data for five therapeutic proteins. Pharm. Res., 8(11):1351-9, 1991.

Morgan, M. J. Recreational use of "ecstasy" (MDMA) is associated with elevated impulsivity. Neuropsychopharmacology, 19(4):252-64, 1998.

Morley, K. C.; Gallate, J. E.; Hunt, G. E.; Mallet, P. E. \& McGregor, I. S. Increased anxiety and impaired memory in rats 3 months after administration of 3,4-methylenedioxymethamphetamine ("ecstasy"). Eur. J. Pharmacol., 433(1):91-9, 2001.

Murnane, K. S.; Perrine, S. A.; Finton, B. J.; Galloway, M. P.; Howell, L. L. $\&$ Fantegrossi, W. E. Effects of exposure to amphetamine derivatives on passive avoidance performance and the central levels of monoamines and their metabolites in mice: correlations between behavior and neurochemistry. Psychopharmacology (Berl.), 220(3):495-508, 2012.

Myhrer, T. Neurotransmitter systems involved in learning and memory in the rat: a meta-analysis based on studies of four behavioral tasks. Brain Res. Brain Res. Rev., 41(2-3):268-87, 2003.

O'Callaghan, J. P. \& Miller, D. B. Neurotoxicity profiles of substituted amphetamines in the C57BL/6J mouse. J. Pharmacol. Exp. Ther., 270(2):741-51, 1994.

Paxinos, G. \& Watson, C. The Rat Brain in Stereotaxic Coordinates. 6th ed. New York, Academic Press, 2007.

Piper, B. J. \& Meyer, J. S. Memory deficit and reduced anxiety in young adult rats given repeated intermittent MDMA treatment during the periadolescent period. Pharmacol. Biochem. Behav., 79(4):723-31, 2004.

Renoir, T.; Païzanis, E.; El Yacoubi, M.; Saurini, F.; Hanoun, N.; Melfort, M.; Lesch, K. P.; Hamon, M. \& Lanfumey, L. Differential long-term effects of MDMA on the serotoninergic system and hippocampal cell proliferation in 5-HTT knock-out vs. wild-type mice. Int. J. Neuropsychopharmacol., 11(8):1149-62, 2008.

Richards, J. B.; Baggott, M. J.; Sabol, K. E. \& Seiden, L. S. A high-dose methamphetamine regimen results in long-lasting deficits on performance of a reaction-time task. Brain Res., 627(2):254-60, 1993.
Sanders-Bush, E.; Bushing, J. A. \& Sulser, F. Long-term effects of pchloroamphetamine and related drugs on central serotonergic mechanisms. J. Pharmacol. Exp. Ther., 192(1):33-41, 1975.

Santucci, A. C.; Knott, P. J. \& Haroutunian, V. Excessive serotonin release, not depletion, leads to memory impairments in rats. Eur. J. Pharmacol., 295(1):7-17, 1996.

Scatton, B.; Simon, H.; Le Moal M. \& Bischoff, S. Origin of dopaminergic innervation of the rat hippocampal formation. Neurosci. Lett., 18(2):12531,1980 .

Schultz, W. Predictive reward signal of dopamine neurons. J. Neurophysiol., 80(1):1-27, 1998

Shankaran, M. \& Gudelsky, G. A. Effect of 3,4methylenedioxymethamphetamine (MDMA) on hippocampal dopamine and serotonin. Pharmacol. Biochem. Behav., 61(4):361-6, 1998.

Steranka, L.; Bessent, R. \& Sanders-Bush, E. Reversible and irreversible effects of p-chloroamphetamine on brain serotonin in mice. Commun. Psychopharmacol., 1(5):447-54, 1977.

Steranka, L. R. \& Sanders-Bush, E. Long-term effects of continuous exposure to amphetamine on brain dopamine concentration and synaptosomal uptake in mice. Eur. J. Pharmacol., 65(4):439-43, 1980.

Stone, D. M.; Hanson, G. R. \& Gibb, J. W. Differences in the central serotonergic effects of methylenedioxymethamphetamine (MDMA) in mice and rats. Neuropharmacology, 26(11):1657-61, 1987.

Sugimoto, Y.; Ohkura, M.; Inoue, K. \& Yamada, J. Involvement of serotonergic and dopaminergic mechanisms in hyperthermia induced by a serotoninreleasing drug, p-chloroamphetamine in mice. Eur. J. Pharmacol., 430(23):265-8, 2001

Taylor, J. R. \& Jentsch, J. D. Repeated intermittent administration of psychomotor stimulant drugs alters the acquisition of Pavlovian approach behavior in rats: differential effects of cocaine, d-amphetamine and 3,4methylenedioxymethamphetamine ("Ecstasy"). Biol. Psychiatry, 50(2):137-43, 2001.

Williamson, S.; Gossop, M.; Powis, B.; Griffiths, P.; Fountain, J. \& Strang, J. Adverse effects of stimulant drugs in a community sample of drug users. Drug Alcohol Depend., 44(2-3):87-94, 1997.

Wilson, J. M.; Kalasinsky, K. S.; Levey, A. I.; Bergeron, C.; Reiber, G.; Anthony, R. M.; Schmunk, G. A.; Shannak, K.; Haycock, J. W. \& Kish, S. J. Striatal dopamine nerve terminal markers in human, chronic methamphetamine users. Nat. Med., 2(6):699-703, 1996.

Winstanley, C. A.; Dalley, J. W.; Theobald, D. E. \& Robbins, T. W. Fractionating impulsivity: contrasting effects of central 5-HT depletion on different measures of impulsive behavior. Neuropsychopharmacology, 29(7):1331-43, 2004.

Correspondence to:

Dr. Mehrdad Jahanshahi

Department of Anatomy, Neuroscience Research Center

Faculty of Medicine

Golestan University of Medical Sciences

Km 4 Gorgan-Sari road (Shastkola)

Gorgan - IRAN

Received: 16-10-2014

Email: mejahanshahi@yahoo.com

Accepted: 20-01-2015 